\title{
The Role of Semantic Mapping as a While- reading Activity in Improving Reading Comprehension Ability of the Iranian University Students in General English (GE) Courses
}

\author{
Mohammad Reza Mozayan \\ English Language Department, Shahid Sadoughi University of Medical Sciences, Yazd, Iran \\ Email: mozayan38@yahoo.com \\ Ali Mohammad Fazilatfar \\ English Language Department, Yazd University, Yazd, Iran \\ Anahita Khosravi \\ English Language Department, Shahid Sadoughi University of Medical Sciences, Yazd, Iran \\ Jafar Askari \\ Psychology Department, Shahid Sadoughi University of Medical Sciences, Yazd, Iran
}

\begin{abstract}
Of the four important skills in any second language pedagogy, reading comprehension is of paramount importance for students in the Iranian universities. A decision was therefore made to check the students' skill and ability in reading comprehension on the basis of 'semantic mapping' task inYazd Shahid Sadoughi University of Medical Sciences. In this quasi-experimental study, six general-English classes in Shahid Sadoughi University were assigned randomly to 3 control and 3 experimental groups. Students were studying in Family Health, Environmental Health, and Nursing fields. A pretest and posttest was held and the students were compared both at the beginning and at the end of the study. Data were then analyzed through ANOVA and paired-test via SPSS software. The findings revealed no statistically significant relationship between the two techniques. However, 'semantic mapping' technique, in terms of the mean score, proved more effective for Nursing students $(M=6.25)$ compared with the students of Environmental Health $(M=2.60)$ and Family Health $(M=4.62)$. The results of this study are in line with a similar study carried out with medical and dental students (2006) in which the semantic mapping group enjoyed significantly higher reading comprehension ability than the relevant control group at the end of the study. (Note that the Nursing students in Iranian universities have a better position compared with Health-group students but a lower position compared with Medical and Dental students) This study suggests that the higher proficiency level of the learners is the more they may benefit from semantic mapping technique as a while-reading activity.
\end{abstract}

Index Terms - reading comprehension, traditional, semantic mapping

\section{INTRODUCTION}

Over the past few decades, there has emerged a gradual but significant shift of attention from teacher-oriented to learner-oriented classes within the field of education. At the same time, attention has been exercised in SLA research from the products of language learning to the processes through which learning takes place (Oxford 1990).

In an effort to lead learners towards autonomous and independent language learners, research has abundantly focused on learner-centered approaches in second/foreign language teaching. This change in emphasis has resultantly brought about meaning-based activities which are of utmost importance in pedagogical environments (Brown 2000).

\section{A. Fundamental Concepts in Reading Comprehension}

Even though the minimum requirement for appreciation of reading is sharing the code between the writer and the reader, sharing certain assumptions about the world and the way it works is another prerequisite for reading comprehension the lack of which can contribute to comprehension failure. In other words, in addition to the linguistic knowledge necessary for reading "... more intangible things like attitudes, beliefs, values, and all the unspoken assumptions shared by the people brought about in the same society" also need to be considered vital in any reading activity (Nuttall 1996). And for the fact that not two persons always possess identical experiences, there may at times seem a mismatch between the two. We however construct more assumptions on the basis of the experiences of the world we have had as well as the organization of the knowledge provided by these experiences. This concept is best 
represented by schema theory within which thus these two important features can be conceptualized, 1) being mental, and 2) being organized (Richards \& Schmidt 2002), and evidently for readers who do not share the relevant schema, some problems may arise in comprehending any reading material.

Top-down (schematic) and bottom-up (linguistic) processing are also the concepts which have been discussed in the relevant literature on receptive skills for the past decades (Hedge 2000; Nuttall 1996; Richards \& Schmidt 2002; Kaplan 2002; Brown 2000; Scrivener 2011, and many more). In bottom-up processing which is considered a 'lower-level' reading, the reader attempts to draw on some linguistic components such as vocabulary and structure to decode meaning whereas in top-down processing the reader is, by applying prior knowledge, engaged in a 'higher level' reading and extracts meaning by the information present in the input. And as Scrivener [ibid] contends, "many reading lessons move from 'big' to 'small', ie 'top-down' - from overview to details." To Johnson's (2001) identification, "[s]chemata play an important role in comprehension from an early stage in the process. Comprehension doesnot follow a totally bottom-up pathway.... Instead we take short-cuts." Anyway both these types of processing are important and necessary for understanding texts and it is said that by taking an interactive approach to reading, the reader involves in a dynamic relationship with text so as to make sense of it. As ways to speed reading, skimming (ie, reading for the gist of a passage or text) or scanning (ie, to locate a specific piece of information) are also the concepts both of which are regarded as top-down skills; in none of which the focus is on accessing details.

In addition to skimming and scanning as purposeful ways to reading, Pugh (1978) and Gardner(1979) draw on some other terminology to describe various reading styles (as cited in Hedge 2000). Receptive reading, involves for example enjoying a piece of writing, reading in a cook book how to bake a cake, or following an argument between two politicians in a newspaper. Reflective reading is undertaken when the reader attempts to check his or her understanding of a text by moments of pausing to see whether different parts of a text are consistent with each other, or to have a critical view of the material. And, intensive reading which involves both top-down and bottom-up processing for a careful and detailed appreciation of a piece of writing. And finally extensive reading or reading longer texts over time, which has been addressed by many researchers as a powerful way of improving reading ability as well as overall language proficiency. Scrivener (2011) has put it rightly saying" [t]he more someone reads, the more they pick up items of vocabulary and grammar from the text, often without realizing it, and this widening language knowledge seems to increase their overall linguistic confidence, which then influences and improves their skill in other language areas, too (though this is not probably true in cases where the material they read is self-chosen and is genuinely relevant and interesting to them."

\section{B. Reading Comprehension Strategies}

Language learning strategies have also been discussed widely in varying researches (see, e.g., Oxford 1990; Brown 2000; Hadley 2003; Cook 2001; Hedge 2000; Nuttall 1996; Lightbown \& Spada 2003). Oxford (1990) defines language learning strategies as "approaches or techniques that learners use to enhance their progress in developing L2 skills". Cook (2001) defines learning strategies as "a choice that learner makes while learning or using the second language that affects learning". Moreover, Griffiths (2007) states language learning strategies as activities which are consciously chosen by learners for the purpose of regulating their own language learning. Brown (2001) also asserts that languageteaching methodology has undergone a dramatic increase in attention to "strategic investment" that learners can make in the process of their learning. Finally Grab (2002) maintains that metacognitive awareness and strategy learning are useful instructional practices if students are to become strategic readers. A practical application at classroom level and a selection of activities for teaching strategies to pupils has as well been discussed in Ellis and Silinclair's book Learning to Learn English (1989).

In recent years the term "interactive" has been used in literature to describe second language reading process. As Hedge (2000) suggests, the interactive process in reading comprehension shows "a dynamic relationship with text as the reader 'struggles' to make sense of it." In trying to extract meaning from the text, the reader is involved in a kind of process which Goodman (1967) called a "psycholinguistic guessing game" (as cited in Hedge, 2000) in which the learner involves in reading as a kind of dialog between the reader and the author (Widdowson 1978, as Cited in Hedge 2000). This is certainly a kind of a strategy that learners would draw on while reading difficult texts.

In regard with text comprehension, an integration of understanding lexical units, syntactic units, and discourse features which mainly involves inference processing is vital (Perfetti, 1994). The lexical and syntactic units, as Perfetti further maintains, are at a lower level of text representation because the engagement of processes is somewhat passive as compared to the discourse level which is more active. However there is evidence that strategy training or skill teaching can also help (Nuttall, 1996). A skill which is often used by the researchers in this process is called " text attack skills" through which the learners are asked to "underline, circle or draw lines from one word to another, use color to indicate differences in function or structure, block off certain sections, annotate in the margins, and so on" in the process of reading (Nuttall 1996). This is surely what some researchers have regarded as "while-reading" tasks (see e.g., Wallace 2001, as cited in Carter \& Nunan 2001) and "during-reading" technique by others (see e.g., Brown 2001). While-reading task is therefore a nearly recent concept in the interactive approach to reading which has been put forth more clearly by Hedge (2000) in this way:

these [activities] generally aim to encourage learners to be active as they read. Students can be given activities which require them to do any of the following: follow the order of ideas in a text; react to the opinions expressed; understand 
the information it contains; ask themselves questions; make notes; confirm expectations or prior knowledge; or predict the next part of the text by varying clues. To encourage these activities, teachers can use a range of exercise types, for example: ask students to tick a list of expectations or find answers to their own questions; suggest they tick and cross in the margin in reaction to the writer's opinions; give them questions to stop and think about; or provide a chart for them to fill in with points of information.

As teachers, it is surely incumbent on us to recognize our students' reading strategies (maybe through a check list or a Likert-type scale), as we often do in our university, so as to gain access to their Achilles' heel in an attempt to help them develop successful reading strategies. This viewpoint is somehow pertinent to what Widdowson (2003) observes in relation to one difference between classroom language and that which occurs outside in natural discourse. To him language of the classroom is "unilaterally determined and controlled." Otherwise it would become rather difficult to capture the effect the teacher expects of the class.

Another technique described by Hosenfeld et al (1981; cited in Hadley 2003) is to teach students to self-report while they are reading. Learners in this way are encouraged to 'think about' as they tackle a reading task. "As students report their thinking processes, the teacher has an opportunity to diagnose reading difficulties and identify specific reading strategies"

In a study conducted by Hudson (1988; cited in Nunan 1999) on 93 ESL students with different levels of proficiency in the United States, it was demonstrated that students at different levels of proficiency apply different reading strategies. This study found, for example, that lower-level proficiency students benefit more from pre-reading activities).

Drawing upon different skills to improve reading comprehension is a principle that researchers tend to focus on in the world of communicative approach to second/foreign language learning and teaching (Schmitt 2002; Nuttall 1996; Hadley 2003, to name a few).

\section{Reading Process vs. Reading Product}

As with any other skill, reading comprehension also requires to be distinguished when being processed from when it is taken as a product being the result of the process. To date, research has mostly been carried out to address the product of learners' reading activities and what they access to at the final stage of a reading performance. However the reading process during which many different things can take place has mostly been taken for granted. Only recently have researchers come to fully appreciate the significance of reading at process and what the learners do during reading so as to be able to detect how learners acquire a second language. Alderson (2000) delineates the concept of reading process in this way: "[t]he reader is presumably ... thinking about what he is reading: what it means to him, how it relates to other things he has read, to things he knows, to what he expects to come next in texts....He is presumably thinking about how useful, entertaining, boring, crazy, the text is." And then he adds: "[u]nderstanding the process of reading is presumably important to an understanding of the nature of reading, but at the same time it is evidently a difficult thing to do. The process is normally silent, internal, and private." According to Rod Ellis and Barkhuizen (2005), the two currently-used methods of 1) studying what the learners do in their production, and 2) asking them to report when learning, are considered vital ways of collecting samples of learners' language and thereby searching into the process reading; one technique used by the writers of this article is semantic mapping.

\section{Semantic Mapping}

Originally developed by Johnson and Pearson in 1976, semantic mapping technique was first applied to teach vocabulary to children in their L1. It consists of "creating a graphic arrangement of associated clusters around a key word, idea or concept" (Hadley 2003). To Brown (2001) the term defined as "grouping ideas into meaningful clusters" was represented as a kind of strategy in improving reading comprehension that can be worked through by the learners either individually or more productively as a group activity. As Carrel Pharis and Liberto (1998) assert, semantic mapping is a kind of strategy training which can be instructed to improve reading skills (cited in Schmitt, 2002).

Some studies have been carried out to explore the role of semantic mapping in improving reading comprehension skill. Harmer (2007) for example puts forth different type of activities for learners according to their capabilities. He suggests reordering lines or paragraphs as a bottom-up activity for lower-level students, and being engaged in discussion of the concepts in each text through pair- or group-work for higher-level learners. Also on the process of employing tasks to focus on meaning, Scrivener (2011) suggests answering questions about meaning, making use of information in the text to do something (making a sketch, filling out a form, finding which picture is being described, etc) discussing issues, summarizing arguments, and comparing viewpoints.

In an experimental study by Mirhassani and Akhlaghi (2009), the researchers found out this strategy as useful in ameliorating the condition of their subjects at the end of their study. Also in a pilot study which was carried out by the first researcher of this study in 2006, a positive relationship could be detected between reading comprehension improvement of Iranian intermediate-level learners (medical students) and semantic mapping as a while-reading activity.

This study is based on Brown's (2001) concept of semantic mapping task. This study thus intends to investigate the ability of the Iranian EFL lower-intermediate university students in drawing on semantic mapping technique for handling General English (GP) courses offered in Iranian universities as a means to amekiorate their reading comprehension skill. 


\section{E. Research Hypotheses}

In line with an attempt to determine whether semantic mapping can have any effect on improving reading ability of the university students taking GE courses, these null hypotheses were formulated: 1) semantic maps produced by the readers do not improve reading comprehension ability in GE courses; 2) semantic mapping strategy has some relationship with the learners' gender; 3) semantic mapping strategy has some relationship with the learners' major.

\section{MethodolOGY}

\section{A. Participants}

In this research, 180 students of Yazd medical sciences university were selected out of 188 subjects and participated in the study ( eight were set aside as outliers.). All the subjects had obtained pre-requisite requirement for entrance into GE courses. The age range of the subjects was 19-21. The subjects, including both males (417\%) and females (58/3\%) were homogeneous in terms of reading comprehension in their majors (Nursing students, 37.6\%; Environmental Health, $31.5 \%$; and Family Health, 30.9\%).

\section{B. Instrumentation}

To determine the homogeneity of the groups in terms of their reading comprehension ability, the Michigan Test of General English Proficiency was administered to all the subjects. The vocabulary section of the test was removed for it was not related to the purpose of the study; the other two parts, i.e. structure and reading comprehension were used. The posttest consisting of 6 passages with 30 comprehension questions was also administered to measure the subjects' knowledge of communicative strategies in written discourse. A debriefing interview was also held randomly to check the opinion of the learners on semantic mapping task.

\section{Material}

In this study, the student's textbook (English for the Students of Medicine I) constrained by the university curriculum for medical and paramedical GE courses was used for having the following advantages: a) difficulty level of the textbook was geared to the level of the students' prior knowledge; and, b) thanks to using their own textbook, the students most likely could not guess they were participating in a study.

\section{DESIGN AND PROCEDURE}

The present study had a pretest-posttest equivalent-groups design. In this quasi-experimental study, 180 students previously assigned into six classes through university regulations participated in the study. Three were taken as control groups (CGs) and three others as experimental groups (EGs) randomly. Although the subjects had met the requirements of taking GE course (they all had passed Pre-university English in the previous semester) a pretest was held as well to assure the homogeneity of the groups. Afterwards both groups (CGs \& EGs) were assigned to a series of similar instructions except that the EGs were instructed to be involved in semantic mapping as a while-reading activity following reading each paragraph. The difference was that the subjects in the CGs, had, after studying each paragraph of the lessons in their textbook (15 lessons totally), a slight time to think over the gist and then present it orally whereas, the EGs, before presentation, took their time to group their ideas into meaningful clusters on a sheet of paper. Note that all the subjects in both groups worked in subgroups of 3 or 4 at their convenience.

On the whole, the study took as long as one semester of 3-hour-per-week instruction during which 14 reading comprehension lessons were covered. Finally a posttest was administered to all the six groups and the results were analyzed by paired-test and ANOVA via SPSS software.

\section{RESULTS}

Overall the findings of the study indicated no statistical difference between the two procedures.

TABLE 1:

COMPARISON OF MEAN AND STANDARD DEVIATION OF THE DIFFERENCE IN READING COMPREHENSION ABILITY OF THE EGS AND CGS

\begin{tabular}{|l|l|l|l|l|l|l|}
\hline \multirow{2}{*}{$\begin{array}{c}\text { Time of } \\
\text { Variable }\end{array}$} & Before & Mean & SD & Mean & SD \\
\cline { 2 - 7 } & Group & $\begin{array}{l}\text { Dependent t-test } \\
\text { result }\end{array}$ \\
\hline Comprehension & Experimental & 7.88 & 3.68 & 12 & 3.57 \\
\cline { 2 - 7 } $\begin{array}{c}\text { Independent } \\
\text { t-test Result }\end{array}$ & Control & 7.78 & 3.88 & 11.37 & 4.05 & 0.0001 \\
\hline
\end{tabular}

As it is evident from table 1, the mean point of the two sets of groups before the intervention was around 7 (out of 20) thus indicating no statistical difference between the EGs and CGs at the outset.

Moreover, obtaining no statistical difference between the groups at the end of the study indicates no improving effect on reading comprehension ability of the learners through applying semantic mapping strategy. 
TABLE 2:

COMPARISON OF MEAN AND STANDARD DEVIATION OF THE EGS AFTER THE INTERVENTION ON THE BASIS OF THE LEARNERS' MAJOR

\begin{tabular}{|l|l|l|l|l|l|l|l|}
\hline \multirow{2}{*}{ Variable } & Najor & Nursing & Environmental health & \multicolumn{2}{|c|}{ Family health } & \multirow{2}{*}{ ANOVA } \\
\cline { 2 - 7 } & Mean & SD & Mean & SD & Mean & SD \\
\hline Reading comprehension & 6.25 & 3.46 & 2.60 & 3.91 & 4.62 & 3.49 & 0.0001 \\
\hline
\end{tabular}

As the table indicates, semantic mapping task has been more effective with the students of Nursing (although not statistically significant).

TABLE 3:

COMPARISON OF MEAN AND STANDARD DEVIATION OF THE CGS AFTER THE INTERVENTION ON THE BASIS OF THEIR MAJOR

\begin{tabular}{|l|l|l|l|l|l|l|l|}
\hline \multirow{2}{*}{ Variable } & Eajor & Nursing & Environmental health & \multicolumn{2}{l|}{ Family health } & \multirow{2}{*}{ ANOVA } \\
\cline { 2 - 8 } & Mean & SD & Mean & SD & Mean & SD & 2.91 \\
\hline Reading comprehension & 4.47 & 3.75 & 2.50 & 3.83 & 0.0001 & 3.87 \\
\hline
\end{tabular}

The table indicates no statistical difference among different fields of study instructed through the traditional procedure.

TABLE 4:

COMPARISON OF MEAN AND STANDARD DEVIATION OF THE DIFFERENCE IN READING COMPARISON ABILITY OF THE EGS ON THE BASIS OF THEIR GENDER

\begin{tabular}{|l|l|l|l|l|l|}
\hline \multirow{2}{*}{ Gender } & Male & Female & Dependent \\
Variable & Mean & SD & Mean & SD & \\
\hline Reading comprehension & 2.94 & 3.73 & 4.20 & 3.93 & 0.154 \\
\hline
\end{tabular}

As the table shows the instruction applied to EGs has had similar effect on both male and females.

TABLE 5:

COMPARISON OF MEAN AND STANDARD DEVIATION OF THE DIFFERENCE IN READING COMPARISON ABILITY OF THE CGS AND EGS ON THE BASIS OF THEIR GENDER

\begin{tabular}{|l|l|l|l|l|l|}
\hline \multirow{2}{*}{ Variable } & \multicolumn{2}{l|}{ Female } & Mependent \\
\cline { 2 - 6 } & Mean & SD & Mean & SD & \\
\hline Reading comprehension & 4.15 & 5.38 & 4.18 & 3.59 & 0.986 \\
\hline
\end{tabular}

This table also shows that the teaching procedure used for the control groups is not a distinctive feature of comprehension for males and females.

\section{CONCLUSION AND SUGGESTION}

In regard with the fact that for the Iranian EFL learners in the universities specially those whose major is not English language, reading comprehension ability is of utmost importance in academic milieu, this study was carried out. Although the research did not detect any significant relationship between the two procedures applied, the difference among the learners' mean scores (Nursing, 6.25; Environmental Health, 2.6; and family health, 4.62) indicates that students of Nursing with a higher attainment in their "University Entrance Examination" (UEE) may enjoy better with semantic mapping technique.

This is actually in line with what the first researcher of this study found in another research with Medical and Dental students (2006) in which the semantic mapping group enjoyed significantly higher reading comprehension ability than the relevant control group at the end of the study. This can likely be due to the higher English language proficiency of these students as they should also gain a higher stance in UEE compared with Nursing and Health-group students.

This study suggests that the higher proficiency level of the learners is the more they may benefit from semantic mapping technique as a while-reading activity. To put it differently, semantic mapping technique proves more useful with those learners who enjoy an apposite level of language proficiency. This is apparently due to the fact that the less skilled readers must rely highly on context clues (bottom-up processing) to compensate for their inefficient decoding. It follows that students of medicine who, compared with students of other disciplines, enjoy a higher skill and ability in L2 reading, can surely create a more coherent and better mental model which is assumed to be an important feature of discourse processing in understanding texts. This is also consistent with Language Threshold Hypothesis on the basis of which L2 language knowledge plays a significant role in successful fluent reading.

One reason why weaker learners fail to achieve a measureable success in comprehending texts in such situations may be their failure to attend to form. That is because semantic mapping activities are highly meaning-based, inefficient learners do not often notice the underlying structural features necessary for detailed processing of texts, specifically in time-limited contexts, i.e. they do not adequately focus on form to streamline an apposite processing (Ellis, 2008).

Learners also need to understand how texts work and what they have to do when they read, and if they, for example, identify that they fail in understanding a text, find out the reason and 'adopt a strategy' to resolve their problem. This ability that readers reflect on what goes on in their minds and is termed metacognitive strategy is identified as a vital factor in people's capacity to develop as readers (Nuttall 1996). And research has consistently shown that weaker 
learners most often rely more on cognitive but less on metacognitive capacity; this can be regarded as another reason for our subjects' failure.

Interestingly enough, the results of the interview also revealed that the students were not much satisfied with the semantic maps they produced because of not being adequately certain of the appropriateness of their maps resulting from, as they mentioned, a perplexity feeling they had while mapping.

In addition to a focus-on-form and metacognitive approach, if the study could also include pharmacology and midwifery students (because in Iran these students should also gain a better UEE grade as well as a higher English proficiency following medical students), a more dependable conclusion would certainly be reached.

\section{APPENDIX A}

\section{$\underline{\text { A Semantic Map Sample }}$}

1. Longevity

2. Control of preventable diseases

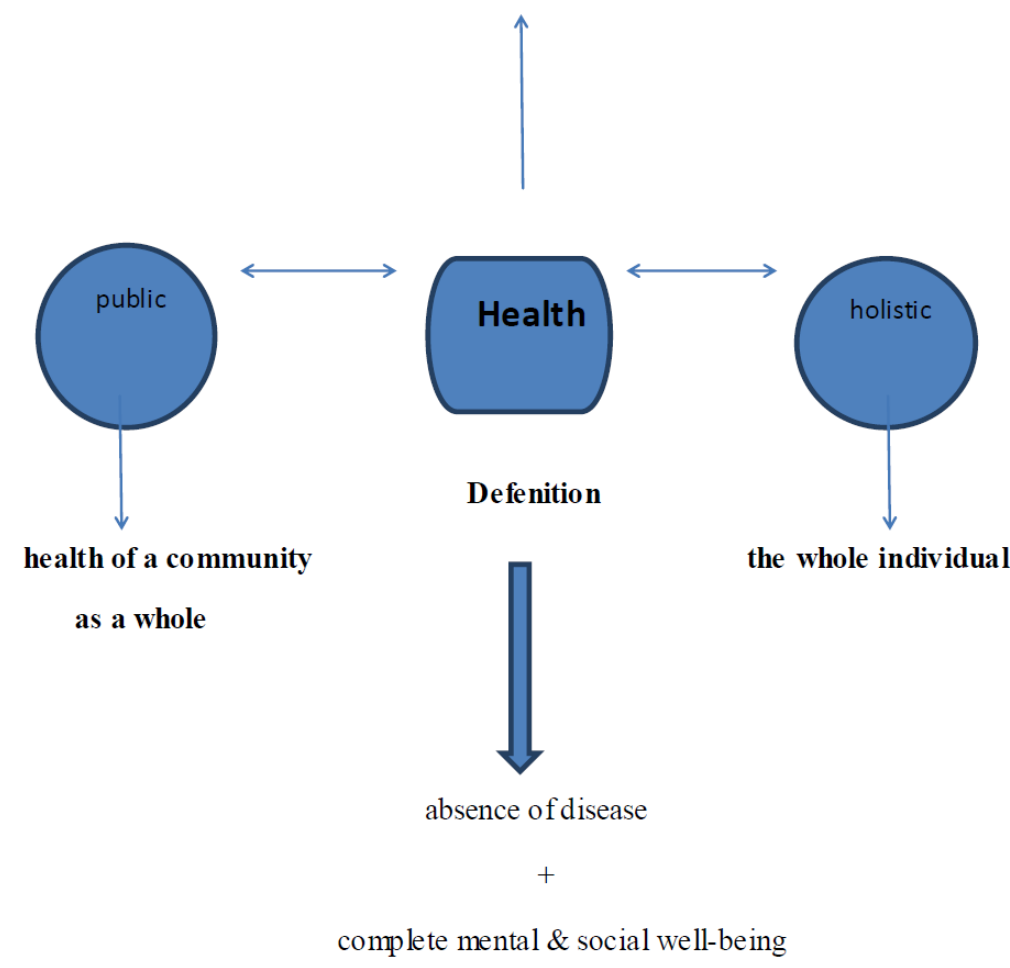

(WHO)

\section{REFERENCES}

[1] Alderson, J. Ch. (2000). Assessing Reading. Cambridge: Cambridge University Press.

[2] Brown, H.D. (2000). Principles of Language Learning and Teaching Longman: Pearson Education Co.

[3] Brown, H.D. (2001). Teaching by Principles: An Interactive Approach to Language Pedagogy (2 ${ }^{\text {nd }}$ Ed). Longman: Pearson Education Co.

[4] Carter, R. \& Nunan, D. (Eds.). (2001). The Cambridge Guide to Teaching English to Speakers of Other Languages. Cambridge: Cambridge University Press.

[5] Cook, V. (2001). Second Language Learning and Language Teaching. London: Edvard Arnold.

[6] Ellis, G. and B. Sinclair. (1989). Learning to Learn English: A course in learner training. Cambridge: Cambridge University Press.

[7] Ellis, R. and G. Barkhuizen. (2005). Analyzing Learner Language. Oxford: Oxford University Press.

[8] Ellis, R. (2008). The Study of Second Language Acquisition. Oxford: Oxford University Press.

[9] Gerami, M. H. \& Gareh Baighlou, B. (2011). Language Learning Strategies Used by Successful and Unsuccessful Iranian EFL Students.

[10] Griffiths, C. (2007). Language Learning Strategies: Students' and Teachers' Perceptions. ElT Journal 61(2), 91-99. 
[11] Grab, W. (2002). Reading in a Second Language. In R. B. Kaplan (Ed.), The Oxford Handbook of Applied Linguistics. Oxford: Oxford University Press, Inc.

[12] Griffiths, C. (2007). Language Learning Strategies: Student's and Teachre's Perceptions. ElT Journal 61(2), 91-99

[13] Harmer, J. (2007). The Practice of English Language Teaching. England: Pearson Education Limited.

[14] Hadley, A.O. (2003). Teaching Language in Context. USA: Heinle \& Heinle Publishers.

[15] Hedge, T. (2000). Teaching and Learning in the Language Classroom. Oxford: Oxford University Press.

[16] Johnson, K. (2001). An Introduction to Foreign Language Learning and Teaching. Longman: Pearson Education.

[17] Kaplan, R. B. (Ed.). (2002). The Oxford Handbook of Applied Linguistics. Oxford: Oxford University Press.

[18] Lightbown, P.M. \& Spada, N. (2003). How Languages Are Learned ( $8^{\text {th }}$ ed.). Oxford: Oxford University Press.

[19] Mirhassani, S. A. \& Akhlaghi, M. (2009). The Effect of Word Association Tasks Through the Use of Semantic Mapping on Reading Comprehension Proficiency among Iranian High School Students. Roshd EFL, 91, 40-46.

[20] Mozayan, M.R. (2006). The Effect of Semantic Mapping on the Improvement of ESP reading Comprehension Ability of Iranian Students. Paper Presented at the First National ESP/EAF Conference. Iran. Tehran.

[21] Nunan, D. (1999). Second Language Teaching \& Learning. USA: Heinle \& Heinle Publishers.

[22] Nuttall, C. (1996). Teaching Reading Skills in a Foreign Language. Oxford: MacMillan Publishers.

[23] Oxford, R. (1990). Language Learning Strategies: What Every Teacher Should Know. Boston: Heinle \& Heinle.

[24] Oxford, R. (1991). What Every Teacher Should Know ( $2^{\text {nd }}$ ed.). New York: Newbury House.

[25] Perfetti, C. A. (1994). "Psycholinguistics and Reading Ability." In M.A. Grenbacher (Ed.) Handbook of Psycholinguistics. San Diego: Academic Press.

[26] Richards, J. C. \& Renandy A.J. (Eds.). (2002). Methodology in language Teaching. UK: Cambridge University Press.

[27] Richards, J. C. \& Schmidt, R. (2002). Dictionary of Language Teaching \&Applied Linguistics (3 ${ }^{\text {rd }}$ ed.). Longman: Pearson Education Limited.

[28] Rose, K. R. \& Kasper, G. (Eds.). (2001). Pragmatics in Language Teaching. Cambridge: Cambridge University Press.

[29] Schmitt, N. (Ed.) (2002). An Introduction to Applied Linguistics. London: Oxford University Press.

[30] Scrivener, J. (2011). Learning English: The Essential Guide to English Language Teaching. (3 ${ }^{\text {rd }}$ Ed.).Oxford: MacMillan Education.

[31] Wallace, C. (2001). Reading. In R. Carter \& D. Nunan (Eds.) (2001). Teaching English to Speakers of Other Languages. UK: Cambridge University Press.

[32] Widdowson, H. G. (2003). Defining Issues in English Language Teaching. Oxford: Oxford University Press.

Mohammad Reza Mozayan was born in Yazd, Iran in 1959, having 22 years of teaching and research background in Iranian universities, MA in Teaching English as a second /Foreign Language and graduated from Tehran-Iran.

$\mathrm{He}$ is now an instructor and a faculty member of medical sciences university in Yazd-Iran and has published several books and articles in some national and international journals. His previous research interest to date has mostly been 'improving reading comprehension ability ' and for now he is attempting to work on students' multiple intelligences. Some of the books published are: Mozayan, M.R. and K. Brazegar. Basic English for Medical and Paramedical Students, Cheragh -e- Denesh publications, Tehran, Iran. 2005. (The second edition of this book was published in 2007.) - Mozayan, M. R. Suffixes, Prefixes \& Roots in Medicine, Asare-Sobhan Publications, Tehran, Iran.1996 (The second edition of this book was published in 2011.) - Mozayan, M. R. et al. Key Sentences in Medical Sciences, Asar-e-Sobhan Publications, Tehran, Iran.2010

Mr Mozayan, MA in TESI/TEFL, has been the head of English Language Department in Yazd Medical University for 22 years.

Ali Mohammad Fazilatfar was born in Yazd, Iran in May 3, 1957. He received his B.A. in TEFL from the Faculty of Foreign Languages of Isfahan University, Iran in 1980. His M.A. in TEFL has also been taken from Tarbiat Modarres University in Iran in 1989. Finally Mr. Fazilatfar finished his PhD. Studies in Applied Linguistics in The University of Manchester in UK in 1998.

He started his career as an academic member of English Dept. in Yazd University in Iran from 1998. He has been teaching different courses including essay writing, linguistics, language teaching methodology, language testing at B.A. and M. A. levels there during the last decade. During the same years he has also been the head of English dept., Director of International Cooperation Office and currently the Vice Dean of the Faculty of Languages and Literature of Yazd University. He has published some articles in peerrefereed journals including: Fazilatfar, A., Ghorbani, S. \& Samavarchi, L. (2011). The effect of standard and reversed subtitling versus no subtitling mode on L2 vocabulary learning. The Journal of Teaching Language Skills (JTLS). 3 (1) 43-64. Mazdayasna, G. \& Fazilatfar, A. (2010). The role of native language in teaching English for specific purposes. Iranian Journal of Applied Linguistics. Vol. 13 (1), 99-124 Fazilatfar, A. \& Beedel, M. (2008). The Iranian students \& teachers' perceptions of the role of explicit grammar instruction \& error correction. TELL. Vol. 2/6. 56-66. His main interests are teaching methodology, language skills, genre analysis, L1 \& L2 reading skills and research methods.

Dr. Fazilatfar as an associate professor of Applied Linguistics at the English Dept. of Yazd University was on sabbatical leave at UCLA in US last year and he is the member of IATEFL, Asia TEFL and MLA at the present time.

Anahita Khosravi was born in Esfahan, Iran in 1977. She received her BA in English Language Translation from Meybod University in Iran in 2000. She started her MA studies in TEFL in 2010. However before starting her MA studies she has been teaching in Iranian high schools for about 10 years and at some of the universities for the last four years.

Her main career has been teaching several courses successfully in Medical Sciences University of Yazd and some other universities. She has also published a book with the cooperation of some university teachers. It is: Mozayan, M. R., Sadeghian, Z., Khosravi A.,Key Sentences in Medical Sciences, Asar-e-Sobhan Publications, Tehran, Iran.2010 
Mrs Khosravi, being a student, is also teaching and researching in SSU of Medical Sciences in Yazd, Iran.

Jafar Askari was born in Shiraz, Iran in 1965. He received his BA in Clinical Psycho logy from Shiraz University and later his MA in the same field from Tehran University in Iran.

He started his career as an employee in psychiatry departments of some of Shiraz hospitals for 8 years and then the opportunity turned up for him to become the faculty member of SSU of Medical Sciences in Yazd, Iran for 15 years on. He has since then published several articles in some domestic and overseas journals one of which is related to Study Skills in Procedia Social and Behavioral Sciences journal.

Mr Askari is now working as an instructor and faculty member in SSU of Medical Sciences in Yazd, Iran. 